\title{
Dividend Policy and Firm Valuation -A Study of Indian Electrical Equipment Manufacturing Industry
}

\author{
Brahmaiah Bezawada1, Ravi Kumar Tati² \\ ${ }^{1}$ ICFAI Business School, IFHE, Hyderabad, India \\ ${ }^{2}$ Manipal University, Dubai, UAE \\ Email: brahmaiahb@yahoo.com, ravi.kumar@manipaldubai.com
}

How to cite this paper: Bezawada, B. and Tati, R.K. (2017) Dividend Policy and Firm Valuation-A Study of Indian Electrical Equipment Manufacturing Industry. Theoretical Economics Letters, 7, 1233-1243. https://doi.org/10.4236/tel.2017.75083

Received: June 3, 2017

Accepted: July 28, 2017

Published: July 31, 2017

Copyright $\odot 2017$ by authors and Scientific Research Publishing Inc. This work is licensed under the Creative Commons Attribution International License (CC BY 4.0).

http://creativecommons.org/licenses/by/4.0/

\begin{abstract}
Dividend policy relevance has been researched extensively, but little consensus has been built from the findings. There are many factors that affect a given firm's dividend policy which can be found in the literature such as risk faced by the firm, cash flow situation of the firm, agency costs etc. According to Bhattacharya (1979) dividend decision of a firm can be seen as a source of signal which shows that profitable firms with good project investment opportunities will pay higher dividends to present themselves distinct from other firms which are having projects with lesser profits. This paper attempts to analyze whether the dividend policy of a firm affects the market value of a firm and the shareholders' wealth. We have set our objective to find out the impact of dividend policy on the shareholders' wealth in the Indian electrical equipment manufacturing industry. For this, we have adopted a sample of dividend paying electrical machinery manufacturing companies listed in Bombay Stock Exchange (BSE). There were totally 439 companies in the industry of electrical machinery manufacturing. Out of them 194 companies were listed in the Bombay Stock Exchange (BSE) and there were 72 companies paying dividends frequently. Therefore the data of these 72 companies were taken into consideration. Our study revealed the empirical evidence with some of the dividend irrelevance theories such as M\&M. The results indicate that there is a negative non-linear association between market value of a share and the dividend yields.
\end{abstract}

\section{Keywords}

Dividend Policy, Firm Valuation, Wealth Maximization 


\section{Introduction}

The returns associated with the shareholders are composed of dividends received and the capital gains. The dividend payout decision of a company has got a direct influence on both of them. So, for management it is a very important function to decide upon whether to pay the dividends or to invest the money back into the company to exploit on other opportunities which result in capital gains. The exact proportion of earnings that the company wants to pay in the form of dividends is tight rope balancing act for the management as the shareholders do prefer dividends in the form of cash as well as appreciation of the securities they hold which results out of reinvested profits. The best and optimal dividend decision is the one that leads to the maximization of the shareholders' wealth through the increased share prices in the market.

The decisions regarding the payment of dividends have to be made in terms of making decision on how much dividend to be paid and in which mode should it be paid. The decision has to be taken considering the available investment avenues and other options of availing finance. If a company is new with investment opportunities and growing robustly, it is natural for it to follow a no payout policy. According to Allen and Michaely [1] there should be a proper knowledge of dividend policy which is important for many other fields like capital structure, Mergers and Acquisitions and Project appraisal and Finance. Without sufficient financial slack, the corporations may face the prospect of having to give up profitable investment opportunities if their securities are underpriced in the presence of information asymmetry-Myers and Majful [2]. So, in this context of importance of dividend policy to the firm and the relevant value maximization associated with it, the electrical machinery manufacturing industry is considered for the study to analyze and find out the importance of dividend policy in that industry. All the companies considered for the study are listed Indian firms.

\section{Literature Review}

Prior research work consists of two diverging views regarding the effect of dividend policy on a firm value. And they are identified as 'Dividend relevance theories' and 'Dividend irrelevance theories'. Both sets of theories give convincing evidences to support their arguments and hence the research dilemma continues till date. Black [3] stated that, "The harder we look at the dividend picture, the more it seems like a puzzle, with pieces that don't fit together". In over thirty years a vast amount of literature has been produced examining dividend policy. Frankfurter et al. [4] concluded in the same vein as Black and Scholes [5] that: The dividend "puzzle", both as a matter of policy and for shareholder value enhancement, is one of the most difficult and most-argued topics in the field of Financial Economics. In a survey, Allen and Michaely [1] concluded that much more empirical and theoretical researches on dividends are required before a consensus can be reached. According to Brealey and Myers [6], dividends are one of the top ten problems which are not resolved in the field of finance. Four 
decades of academic research was not in a position to resolve it. Research in the field of dividend policy shows that a coming to a consensus on it is highly impossible and also shows that the practice of corporate dividend policy is different among different firms as well as different countries.

Dividend policy relevance has been researched extensively, but little consensus has been built from the findings. Three different positions have been taken on the relevance of dividends. Graham and Dodd [7] advocated investors' preference for dividends because of the certainty of dividends compared to the uncertainty of capital gains. The classic work of Modigliani and Miller (M\&M) [8] established the hypothesis that dividend policy is irrelevant to the value of the firm. The M\&M irrelevance proposition was first developed for a world without taxes, and was later extended by Black \& Scholes [5] and Miller et al. [9] to include taxes. The "capital gains tax effect" is a third position on dividend relevance introduced by Farrar et al. [10]. According to this view, the influence of dividend yield on returns (value) is hypothesized to be positive (negative), since the tax on capital gains is lower than the tax on dividend income. Empirical tests of dividend relevance have been based on models that add dividend yield measures to the Capital Asset Pricing Model (CAPM).

Transaction costs come in favor of dividends as a supporting argument. A shareholder who is in need of frequent income from his shareholdings of a company has got two choices. One is to buy the stocks which pay dividends and cashing the dividends, the other one being that of purchasing a non-dividend paying shares and frequently selling a part of the portfolio. For a small individual investor the transaction costs of cashing in the dividends may be significantly smaller than the transaction costs associated with selling a part of the stocksAllen and Michaelly [11].

The theory of Gordon [12] which is famously known as "Bird in hand theory" is in favor of outside shareholders preferring a high dividend payout. For them, a certain dividend payment today is more satisfactory than highly uncertain capital gains in the future. Prior research studies show that the above model will fail if it is applied to a perfect and complete market where investors behave in a rational way-Miller and Modigliani [8]; Bhattacharya, [13]. But, still the actual rationale of Gordon [12] is very often cited.

According to the theory on dividends developed by Shefrin and Statman [14], dividends can make a big difference to the shareholders based on whether that cash is coming in the form of dividends or capital gains, even though the quantum of cash received is the same. In their theory which is a behavioral theory model, shareholders prefer dividends because of self-control. This point is valid to shareholders who want to make themselves restricted from spending too much in the short term. These investors don't want to dispose their capital and, therefore, they are only interested in consuming the current income in the form of dividends. Shefrin and Statman [14] refer to this as the "behavioral life cycle" because this is particularly true in the case of retired citizens who don't have their current income and have to rely mostly on their savings or income from 
their shareholdings. This theory of behavioral life cycle has similarities with that of the Gordon's [12] theory. However, Gordon's theory is based on uncertainty towards future income in terms of dividends, the theory of Shefrin and Statman [14] is related to shareholders whose preference is to consume from current certain dividends than that of the uncertain future capital gains.

There are many factors that affect a given firm's dividend policy which can be found in the literature. Numerous factors such as risk faced by the firm, cash flow situation of the firm, agency costs (including agency costs of debt and agency costs of equity), growth opportunities, taxation, etc. have been found out in prior research literature that affect the dividend policy decisions of a firm. The most important signal showing a firm's ability to pay dividends is the profits made by the firm. According to the research conducted by Linter [15] to find out how the managers of the companies in United States take decisions regarding dividend payments revealed some important findings that the payment of dividend by a firm is affected by the current year's earnings and prior year's dividend payments. He could do it by developing a very good mathematical model based on his research of twenty eight big U.S. firms. The research by Baker, Farrelly and Edelman [16] on over 300 NYSE firms could come to a conclusion that the main factors of influencing dividend payments are the expected level of earnings in the long term and the dividends paid in the past.

The research done by Pruitt and Gitman [17] by interviewing various people of the management concerned with the financial decisions of the firm of a large number U.S. of firms and found supporting evidence for the prior literature that the current and past years' profits of the firm are important parameters which influence the dividend decisions of the firm. Another type of finding in this regard is given by Baker and Powell [18] from their research of New York stock Exchange listed firms and found out that the factors influencing dividends are different for different industries and the also the expected level of earnings in the future. Pruitt and Gitman [17] also found that the risk involved in year to year profits also play a major role in the dividend policy decision of a firm. Firms with more stable earnings are often able to have a better idea of their future earnings. These types of firms are more inclined to pay better proportion of their earnings as dividends than the firms with uncertain or uneven earnings.

Other researchers like Rozeff [19] made use of the beta of the firm as a proxy for risk associated with the market and could find a negative relationship between dividend payout and risk in the market. The outcomes from their research explain the fact the phenomenon that companies with high level of risk pay dividends less frequently. The results of D'Souza [20] gave support to the above results.

Another important factor which influences the dividend payout decision of a firm is the cash position of the firm. A weak cash position means that the firm can give out good cash dividends due to the unavailability of sufficient cash. According to Ali et al. [21] the dividend payout decisions of a firm depend mostly on the liquidity position which shows the firm's ability to give dividends. 
They conclude that the current profits will not affect the firm's dividend paying abilities.

Green et al. [22] investigated the statement that dividend is irrelevant and found out the relationship between financing, investing and dividend decisions. The work done by they proved that the level of dividend payout is not totally dependent on a firm's investment and financing decisions. Their study showed that dividend payout levels are not totally decided after a firm's investment and financing decisions have been made and the decision on dividend is taken in the presence of investment and financing decisions. Their results do not match the views of Miller and Modigliani [8]. But, according to Partington, the firms set certain payout ratios as target and the companies' investment policy does not impact their dividend policy decisions and the extent to which dividends are announced.

Higgins [23] attempted to establish a relationship between the growth of the firms and their financial requirements. The firms with robust growth need finance from outside sources since the cash flows for working capital needs are generally more than the cash flows from the new sales. Higgins [24] could conclude that the dividend payout ratios are related in a negative way with respect to the financing of new investment opportunities. Rozeff [19] could show a negative association between dividend payments and sales which is significant. But, D'Souza [20] showed that an insignificant and positive association exists between dividend payout and growth of the firm, and a negative insignificant relation exists between market to book value and dividend payout ratio.

According to Bhattacharya [13] dividend decision of a firm can be seen as a source of signal which shows that profitable firms with good project investment opportunities will pay higher dividends in order to separate themselves from other firms which are having projects with fewer profits. They show some evidence of firms which are having higher value provide a positive dividend payments with respect to risk associated with the firm. Also, Miller and Rock [25] proved in the same way as Bhattacharya [13] that asymmetries regarding the information between the inside shareholders and outside shareholders will help a signaling role for dividends. They also could prove that dividend decisions will help in spreading private information in a fully transparent manner. The most essential factor in their work is that firms have to give dividends frequently. The dividend payout decision will be taken as a positive signal and accordingly the value of the stock prices appreciate. The firms with good performance only can send such a type of signal to the shareholders and poorly performing firms cannot do this because of the costs involved in doing this and hence a similar logic is applied to the process of share buybacks.

There are a few studies on the importance of dividend policy in the Indian context also. Kanwal and Kapoor [26] tried to identify the various factors that influence the dividend payout policy decisions of the Indian IT firms. They mainly focused on the identification of whether the various factors available in the literature influence the dividend payout ratio in IT sector India in the current 
scenario. They examined the dividend payout ratios of CNX IT listed companies in India and they found that the existing variables available as per literature do not explain the dividend payout pattern of IT sector in India. Only liquidity and Beta which is the year on year variability in earnings are found significant. According to their results the existing literature could explain only $27 \%$ of the Indian Information Technology dividend behavior. They concluded that the influence of price earnings ratio, debt equity ratio on dividend payout policy would be an interesting work.

Azhagiah and Priya [27] tried to analyze the impact of dividend policy on shareholders' wealth in Organic and Inorganic chemical companies in India during the period 1996-1997 to 2005-2006. They used multiple regression techniques and stepwise regression models for their study by taking Dividend per share, Retained earnings, lagged price earnings ratio and lagged market price as the independent variables. Market price per share was taken as the dependent variable. Their study proved that there is a significant impact of dividend policy on shareholders' wealth in Organic companies while there was no significant impact of dividend policy on the shareholders' wealth in the Inorganic chemical companies.

\section{Objective of the Study}

Indian companies provide a better scope for analyzing dividend policy issues for the following reasons; first, most dividend policy research studies are based on samples of free economic markets. Next, compared to the capital markets of developed countries, India's markets are more fledging in nature. Stock investors in India are less educated than those in developed countries. Indian stock investors may show different attitudes and behaviors toward risk-taking, investment, and dividend policy. India is exhibiting ever greater economic influence in the globalized world. Its economic growth rate, current account surplus, and stock market performance demonstrate healthy economics. Shareholders' wealth is represented in the market price of the company's common stock, which in turn, is the function of the company's investment, financing and dividend decision. This paper attempts to analyze whether the dividend policy of a firm affects the market price of a firm and this in turn affects the shareholders' wealth.

In the above context, the objective of the present study is to find out the impact of dividend policy on the shareholders' wealth in the Indian electrical equipment manufacturing industry. We have adopted a sample of dividend paying electrical machinery manufacturing companies listed in Bombay Stock Exchange (BSE). The rationale behind selecting this industry is that it is one of the well-established industries in India with large number of players. Hence it provides enough samples and historical data to make the results more meaningful.

\section{Methodology}

The following hypothesis has been formulated for the present study. 
$\mathrm{H}_{\mathrm{o}}$ : There is no significant impact of dividend policy on shareholders' wealth of the electrical machinery manufacturing companies in India.

$\mathrm{H}_{\mathrm{a}}$ : There is a significant impact of dividend policy on shareholders' wealth of the electrical machinery manufacturing companies in India.

\section{Data}

Data was collected from the Center for Monitoring Indian Economy (CMIE) Prowess database for a time period of ten years i.e. from financial years 19981999 to 2013-2014. There were totally 439 companies in the industry of electrical machinery manufacturing. Out of them 194 companies were listed in the Bombay Stock Exchange (BSE) and there were 72 companies paying dividends frequently. Therefore the data of these 72 companies was taken into consideration.

\section{Variables}

Fama \& French [28] have documented that price to book value (P/B ratio) explains mean stock returns, accompanied by conjectures that is a proxy for risk or an indicator of distress, the difference between market and book average. Hence it was taken as an alternative for shareholders' wealth. Tobin's $Q$ ratio was used as a proxy for $\mathrm{P} / \mathrm{B}$ ratio and taken as the dependent variable. It can be defined as the ratio of Market Value (MV) and Book Value (BV) of assets. MV of a firm is taken the sum of MV of equity and debts (short-term as well as long-term). Since debts are not publicly traded in Indian secondary markets, BV of debts and preference shares have been taken for calculating Tobin's Q. According to Mohanty [29], the Tobin's Q ratio is highly correlated with the Price-to-Book value of the firm and PBV ratio is usually treated as a proxy for risk.

$$
\mathrm{Q}=(\text { Market Value of Equity + Preference Shares + Debt }) / \text { Total Assets }
$$

To remove the market volatility from the analysis, the average of 365 days' closing prices were considered. In computing total assets, all the relevant items on the assets side of the balance sheet were considered. Dividend yield was the independent variable considered and it was taken as proxy for the dividend policy of the firm. Dividend yield can be calculated as the ratio of dividend per share (DPS) to price of the share. The control variables considered were Log (Sales), Return on Capital Employed (ROCE) and Sales growth rate.

\section{Model}

The following model has been proposed to measure the effect of dividend yield on Tobin's Q measure. Ordinary least squares (OLS) method has been used to investigate whether dividend policy has significant association with the shareholders' wealth or not.

$$
\begin{aligned}
\text { Tobin's } \mathrm{Q}= & \alpha+\beta_{1} \text { Dividend Yield }+\beta_{2} \log (\text { Sales }) \\
& +\beta_{3} \text { ROCE }+\beta_{4} \text { Growth Rate }+\varepsilon
\end{aligned}
$$


Table 1. Results of Regression showing the impact of dividend yield on Tobin's Q ratio of the Electrical machinery manufacturing companies in India.

\begin{tabular}{|c|c|c|c|c|c|}
\hline \multicolumn{6}{|c|}{ Regression Model } \\
\hline \multirow{2}{*}{$\begin{array}{l}\text { Independent } \\
\text { Variables }\end{array}$} & \multicolumn{2}{|c|}{ Unstandardized Coefficients } & \multirow{2}{*}{$\begin{array}{c}\text { Standardized Coefficients } \\
\text { Beta }\end{array}$} & \multirow{2}{*}{$\mathrm{t}$} & \multirow{2}{*}{ Sig } \\
\hline & $\mathrm{B}$ & Std. Error & & & \\
\hline Intercept & 0.493 & 0.119 & & 4.419 & 0.000 \\
\hline DivYield & -1.535 & 0.206 & -0.304 & -7.432 & 0.000 \\
\hline Log Sales & 0.066 & 0.023 & 0.125 & 2.850 & $0.005^{*}$ \\
\hline Roce & 3.434 & 0.304 & 0.516 & 11.301 & $0.000^{*}$ \\
\hline Growth Rate & -0.225 & 0.098 & -0.102 & -2.299 & $0.022^{*}$ \\
\hline
\end{tabular}

${ }^{*}$ Significant at $1 \%$ level; ${ }^{*}$ Significant at $5 \%$ level.

\begin{tabular}{cc}
\hline \multicolumn{2}{c}{ Model Summary } \\
\hline $\mathrm{R}^{2}$ & 0.385 \\
Adjusted $\mathrm{R}^{2}$ & 0.378 \\
F value & $57.890^{\star}$ \\
Standard error of the estimate & 0.610 \\
\hline
\end{tabular}

${ }^{*}$ Significant at $1 \%$ level.

\section{Results and Discussion}

\section{See Table 1.}

From the regression results for the overall sample, it is evident that the variables included in this model explain the Tobin's $Q$ ratio at statistically significant level, as indicated by the $F$-statistic ( $1 \%$ level of significance). The adjusted $\mathrm{R}^{2}$ is 0.378 , which means that the model is explaining $37 \%$ of the variation in Tobin's Q. A more detailed examination of the explanatory factors reveals that Dividend Yield is statistically significant at $1 \%$ level of significance. For the overall sample, it has been found that Dividend policy has a significant impact on the shareholders' wealth of the electrical machinery manufacturing companies in India.

\section{Conclusions}

Our study has presented empirical evidence with some of the dividend irrelevance theories such as $\mathrm{M} \& \mathrm{M}$. The results indicate that there is a negative nonlinear association between market value of a share and the dividend yields. Higher dividend decreases the market value of the share and vice-versa. Our results are also in line with the information content or dividend signaling theory by Bhattacharya [13], John and Williams [30], Miller and Rock [25]. These findings are also consistent with empirical evidence of Allen and Michaely [1] Gordon [12], Ross et al. [31], Shefrin and Statman [14], Easterbook [32], and that dividend policy affects a firm's share price. The rational argument in favor of dividends consists of transaction cost according to Allen and Michaelly [11]. 
Our results are similar to some of the results such as Amidu [33] where his study supports second school of thought that dividend policy is relevant to the firm's performance. Surprisingly the study reveals that bigger firms on Ghana Stock Exchange perform less with respect to return on assets which has been taken as the performance measure. Azhagaiah and Priya [27] showed that for Indian Organic chemical companies, there is significant impact of dividend policy on shareholders' wealth but there is no influence of dividend policy as far as Inorganic chemical companies are concerned. Our results differ with some of the studies like that of Stevens and Jose [34], where they have found a significant negative relationship between dividend smoothing and firm value. Their study provided an interesting contrast to the highly significant positive effect of the dividend stability measure, suggesting that artificially stabilized dividends through smoothing are discounted.

In general, as mentioned in the literature review, the higher dividend payments by the firms will help the value of their shares to increase and vice-versa. The shareholders of a company mostly like the present and certain dividends to the future uncertain capital gains. This is generally true with the case of middle class people who mostly depend on their monthly salaries for their living and India consists of mostly middle class individuals. Our study could support some of the earlier studies and does not support some other earlier studies.

\section{References}

[1] Allen, F. and Michaely, R. (1995) Dividend Policy. In: Handbook in OR\&MS, Elsevier Science, Vol. 9, 793-836.

[2] Myers, S.C. (1984) Corporate Financing and Investment Decisions when Firms have Information that Investors Do Not Have. Journal of Financial Economics, 13, 187221. https://doi.org/10.1016/0304-405X(84)90023-0

[3] Black, F. (1976) The Dividend Puzzle. Journal of Portfolio Management, 2, 5-8. https://doi.org/10.3905/jpm.1976.408558

[4] Frankfurter, M., Kosedag, A., Chiang, K., Collison, D., Power, D.M., Scmidt, H., So, R. and Topalov, M. (2002) A Comparative Analysis of Perception of Dividends by Financial Managers. Journal of Research in International Business and Finance, 18, 73-114. https://doi.org/10.1016/j.ribaf.2004.02.002

[5] Black, F. and Scholes, M. (1974) The Effects of Dividend Policy on Common Stock Prices and Returns. Journal of Financial Economics, 2, 1-22. https://doi.org/10.1016/0304-405X(74)90006-3

[6] Brealey, R. and Myers, S. (2005) Principles of Corporate Finance. 8th Edition, McGraw-Hill, London.

[7] Graham, B. and Dodd, D.L. (1951) Security Analysis. McGraw-Hill, New York.

[8] Modigliani, F. and Miller, M.H. (1961) Dividend Policy, Growth, and the Valuation of Shares. Journal of Business, 34, 235-264.

[9] Miller, M.H. and Scholes, M.S. (1982) Dividends and Taxes: Some Empirical Evidence. Journal of Political Economy, 90, 1118-1141. https://doi.org/10.1086/261114

[10] Farrar, D. and Selwyn, L. (1967) Taxes, Corporate Policy, and Return to Investors. National Tax Journal, 20, 444-454. 
[11] Franklin, A. and Michaely, R. (2002) Payout Policy. Center for Financial Institutions Working Papers, 01-02. Wharton School for Financial Studies, Philadelphia.

[12] Myron, G. (1962) The Savings, Investment and Valuation of a Corporation. Review of Economics and Statistics, 45, 37-51.

[13] Bhattacharya, S. (1979) Imperfect Information, Dividend Policy, and "The Bird in the Hand" Fallacy. The Bell Journal of Economics, 10, 259-270. https://doi.org/10.2307/3003330

[14] Shefrin, H.M. and Statman, M. (1984) Explaining Investor Preference for Cash Dividend. Journal of Financial Economics, 3, 253-282. https://doi.org/10.1016/0304-405X(84)90025-4

[15] Lintner, J. (1956) Distribution of Income of Corporations among Dividends, Retained Earnings and Taxes. American Economic Review, 40, 97-113.

[16] Baker, K., Farrelly, H. and Edelman, B. (1985) A Survey of Management Views on Dividend Policy. Financial Management, 14, 78-84. https://doi.org/10.2307/3665062

[17] Pruitt, S.W. and Gitman, L.W. (1991) The Interactions between the Investment, Financing, and Dividend Decisions of Major US Firms. Financial Review, 26, 409-430. https://doi.org/10.1111/j.1540-6288.1991.tb00388.x

[18] Baker, H.K. and Garry, E.P. (2000) Determinants of Corporate Dividend Policy: A Survey of NYSE Firms. Financial Practice and Education, 9, 29-40.

[19] Rozeff, M. (1982) Growth, Beta, and Agency Costs as Determinants of Dividend Payout Ratios. Journal of Financial Research, 5, 249-260. https://doi.org/10.1111/j.1475-6803.1982.tb00299.x

[20] D’Souza, J. (1999) Agency Cost, Market Risk, Investment Opportunities and Dividend Policy-An International Perspective. Managerial Finance, 25, 35-43. https://doi.org/10.1108/03074359910765993

[21] Ali, K.L., Khan, A.Q. and Ramirez, G.G. (1993) Determinants of Corporate Dividend Policy: A Factorial Analysis. The Financial Review, 28, 523-547. https://doi.org/10.1111/j.1540-6288.1993.tb01361.x

[22] Green, P., Pogue, M. and Watson, I. (1993) Dividend Policy and Its Relationship to Investment and Financing Policies: Empirical Evidence Using Irish Data. Ibar, 14, 69-83.

[23] Higgins, R.C. (1981) Sustainable Growth under Inflation. Financial Management, 10, 36-40. https://doi.org/10.2307/3665217

[24] Higgins, R.C. (1972) The Corporate Dividend-Saving Decision. Journal of Financial and Quantitative Analysis, 7, 1527-1541. https://doi.org/10.2307/2329932

[25] Miller, M.H. and Rock, K. (1985) Dividend Policy under Asymmetric Information. Journal of Finance, 40, 1031-1051. https://doi.org/10.1111/j.1540-6261.1985.tb02362.x

[26] Anil, K. and Kapoor, S. (2008) Determinants of Dividend Payout Ratios-A Study of Indian Information Technology Sector. International Research Journal of Finance and Economics, 450, 63-73.

[27] Azhagaiah, R. and Sabari, P.N. (2008) The Impact of Dividend Policy on Shareholders' Wealth. International Research Journal of Finance and Economics, 14502887, $180-188$.

[28] Eugene, F. and French, K. (2001) Disappearing Dividends: Changing Firm Characteristics or Lower propensity to Pay? Journal of Financial Economics, 60, 3-43. https://doi.org/10.1016/S0304-405X(01)00038-1

[29] Mohanty, P. (2003) Institutional Investors and Corporate Governance in India. Research Paper of National Stock Exchange, Mumbai. Vol. 32, 1-37. 
[30] John, K. and Williams, J. (1985) Dividends, Dilution and Taxes: A Signalling Equilibrium. Journal of Finance, 40, 1053-1070. https://doi.org/10.1111/j.1540-6261.1985.tb02363.x

[31] Ross, S.A., Westerfield, R.W. and Jaffe, J. (2002) Corporate Finance. 6th Edition, McGraw-Hill, New York.

[32] Frank, H.E. (1984) Two Agency, Cost Explanation of Dividends. The American Economic Review, 74, 650-659.

[33] Mohammed, A. (2007) How Does Dividend Policy Affect Performance of the Firm on Ghana Stock Exchange? Investment Management and Financial Innovations, 4, 103-114.

[34] Jerry, L.S. and Manual, L.J. (1992) The Effects of Dividend Payout, Stability and Smoothening of Firms' Value. Journal Accounting, Auditing and Finance, 7, 213. https://doi.org/10.1177/0148558X9200700208

Submit or recommend next manuscript to SCIRP and we will provide best service for you:

Accepting pre-submission inquiries through Email, Facebook, LinkedIn, Twitter, etc. A wide selection of journals (inclusive of 9 subjects, more than 200 journals)

Providing 24-hour high-quality service

User-friendly online submission system

Fair and swift peer-review system

Efficient typesetting and proofreading procedure

Display of the result of downloads and visits, as well as the number of cited articles

Maximum dissemination of your research work

Submit your manuscript at: http://papersubmission.scirp.org/

Or contact tel@scirp.org 